\title{
Albert Schweitzer se etiese gesigseinder: Eerbied vir en dankbaarheid teenoor die lewe
}

\author{
Botha, Pieter JJ \\ Universiteit van Suid-Afrika \\ bothapjj@unisa.ac.za
}

\begin{abstract}
Albert Schweitzer's ethical horizon: reverence and gratitude for life

In the search for relevant theology, especially in the context of the ethical and moral challenges facing contemporary South Africa, the theology/philosophy of religion of Albert Schweitzer can play an important role. Aspects of Schweitzer's deliberations are briefly discussed under three topics: ethical mysticism, the centrality of life and the responsibility associated with living. The famous statement, "reverence for life" as summary for Schweitzer's thinking is embedded in profound and comprehensive reflection, and properly understood can provide meaningful support to contemporary theologies struggling with the faith-action divide.
\end{abstract}

Keywords

Schweitzer, Albert, Ethics, life-view, reverence for life, responsibility, good fortune obligates

\section{Op soek na "nuwe" teologie}

Die teologiese gesprek in Suid-Afrika vertoon 'n opvallende besorgdheid oor moraliteit en hierdie belangstelling word meestal verbind met die behoefte aan nuwe of vars teologie. Hierdie aandag kenmerk nie alle publikasies van Suid-Afrikaanse teoloë in dieselfde mate nie, maar die kwessie van hoe geloof by etiek uitkom laat 'n duidelik naspeurbare spoor in ons teologiese navorsing. Dit is natuurlik verstaanbaar: ons geskiedenis én huidige situasie vertoon 'n gebrek aan etiese welslae ten spyte van die wye teenwoordigheid van die Christendom in Suid-Afrika.

Om die soektog na integriteit in woord en daad, na 'n noue band tussen belydenis en optrede, in Suid-Afrikaanse teologiese publikasies te illustreer 
kan talle studies aangehaal word. Enkele (eklekties geselekteerde) sulke skrywes word na verwys. Sonder dat dit sy fokus is, speel dit byvoorbeeld 'n rol in De Gruchy (2015) se huldeblyk aan Beyers Naude, waar hy Naude beskryf as 'n toonbeeld van 'n "new style of being Christian in the world". Hierdie nuwe styl behels integriteit in woord en daad, in belydenis en weerstand. De Gruchy se bespreking maak duidelik dat Beyers Naude (syns insiens) 'n uitsonderlike geval is, juis nie tipies van die Suid-Afrikaanse samelewing nie en, word gesuggereer, presies wat ons nodig het, veral gegewe ons verlede.

Oliver weer verkies om te betoog dat daar na 'n nuwe geestelikheid (spirituality) gesoek moet word, 'n vars nuwe verhouding met Christus vir 'n nuwe christelike identiteit, maar die onderliggende besorgdheid oor geloof en daad speel 'n duidelike rol (Oliver 2006). Elders wys sy daarop dat die "reason behind the contrast between theory and practice must be investigated" (Oliver 2010). De Villiers (2003) bespreek die verwarring wat in kerklike en teologiese kringe bestaan oor hoe openbare moraliteit in Suid-Afrika aangepak moet word. Die lys van voorbeelde van hierdie besorgdheid word vinnig baie lank, maar dit val op dat een besondere bron wat die diskoers behoort te stimuleer selde aangehaal word. In die soeke na "nuwe" teologie - of dan eerder, na 'n "beter" teologie - behoort ons die denke van Albert Schweitzer in berekening te bring. ${ }^{1}$

Albert Schweitzer (1875-1965) was 'n musikus, predikant, filosoof, teoloog en medikus. Hy publiseer (onder meer) 'n kritiese beoordeling van die historiese Jesus navorsing (1913a; 2000b) en 'n belangrike ondersoek na Paulus se mistiek (1931b; 1953). Terwyl hy hoof van die Teologiese Skool van St Thomas (Straatsburg) was besluit hy in Oktober 1905 om 'n mediese dokter te word; in 1913 vestig hy en sy vrou Hélène hulle by Lambaréné (in die huidige Gaboen) en rig 'n hospitaal daar op. Die res van sy lewe wy hy hom toe aan dié mediese taak. As Duitse burger is hy as 'n krygsgevangene in Frankryk aangehou tydens die Eerste Wêreldoorlog. In 1924 keer hy terug

1 Daar is wel enkele plaaslike studies wat Albert Schweitzer betrek (bv Mason 1994; Buitendag 2004), of na hom verwys om aspekte van 'n betoog te ondersteun (bv Botha 1998:400). Uiteraard ontvang Schweitzer se Jesus-studies aandag vanaf SuidAfrikaanse Nuwe-Testamentici (voorbeelde is Craffert 2003; Van Aarde 2003 en Scheffler 1999). Omvattende analise van Schweitzer se teologie/filosofie is egter nie tot op hede prominent in die Suid-Afrikaanse konteks nie. 
na Lambaréné. Hy publiseer die eerste twee dele van die Kulturphilosophie ${ }^{2}$ asook godsdiensfilosofiese studies (Schweitzer 1939; 1936b). In verskeie publikasies en in sommige preke ${ }^{3}$ kenmerk hy sy filosofie as Ehrfurcht vor dem Leben. In 1952 is die Nobelprys vir vrede aan hom toegeken.

\subsection{Is Schweitzer enigsins nog relevant?}

Talle teologiese swaargewigte van die twintigste eeu maak Schweitzer af as sonder noemenswaardige bydrae. Daar is erkenning vir hom as weldoener maar die teologiese spektrum is vol verwerpings van Schweitzer as teologiese of filosofiese denker. Selfs as etikus word sy bydrae met aansienlike skeptisisme bejeën. Eerbied vir lewe word geag as niks anders as ad hoc besluitneming nie (byvoorbeeld Birch en $\mathrm{Cobb}^{4}$ ), dit veronderstel 'n onmenslike absoluutheid van lewe wat die verskil tussen "hoër" en "laer" lewensvorme misken (Brunner 1947:124, asook Banning 1972:7172), dit is teologies onvoldoende (aldus Brunner 1947:195 en veral Karl Barth $^{5}$ ), dit is blote filosofie en in wese onchristelik (Langfeldt 1960:14, 115; Kraus 1944:49). Schweitzer se "eerbied vir lewe" word as onbybels afgemaak (Cullmann 1967:31-32, 406), as panteïsties, sentimenteel en humanisties (Brunner 1947:124, 195, 602 n.4), en dit behels 'n miskenning

2 Schweitzer 1923a; 1923b. Die werk is nooit deur hom voltooi nie; die aantekeninge en voorlopige teksgedeeltes van die derde deel kan in sy Nachlaß geraadpleeg word (Schweitzer 1999; 2000a).

3 Schweitzer was 'n toegewyde prediker en talle van sy preke is gepubliseer (Schweitzer 1966; 1986; 2003).

4 Dit sê dat Schweitzer "the one great Western twentieth-century thinker" is "who took seriously the value of all living things" en erken dat hy talle beïnvloed het, maar Schweitzer se etiek "did not gain expression in practical guidelines" (Birch \& Cobb 1981:148); dit is subjektief en kan net toevallige tersaaklikheid hê (Birch, et al. 1981:149).

5 Barth betoog wel vir die belang van nie-menslike lewe vir 'n christelike sedeleer; die opdrag van God is die opdrag van lewe, en respek vir lewe is belangrik (bv. Barth 1961:324-470), maar eerbied vir die lewe "is only one component or modification of God's command" (Barth 1981:121), en Schweitzer se omvattende aanspraak kan nie gebaseer wees op werklike gehoorsaamheid aan God se Woord nie en daarom nie teologies nie. In 'n brief aan Eduard Thurneysen (15 Nov 1928) beskryf Barth Schweitzer se opvatting as "saftige Werkgerechtigkeit" en dat Schweitzer "sei ein Mensch des 18.Jahrhunderts". "Es hat keinen Sinn, mit ihm zanken zu wollen. Er [Schweitzer] sieht auch sich selber relative wie alles und alle, und daß man mitleidig sein soll, ist ja sicher wahr und auch für uns immer wieder zu bedenken". Sien Schweitzer 2006:69 nommer 11.

6 "In the case of Albert Schweitzer the results of his exegetical research are out of balance with his philosophy of 'reverence for life"' (Cullmann 1967:40). Ook: in sy teologie verwerp Schweitzer die kern van Nuwe-Testamentiese geloof (Cullmann 1962:30). 
van die eskatologiese - "he had no eschatological sense at all ... neither for theological nor for philosophical eschatology" (Moltmann 1967:38-39; ook Robinson 1983:34; Cullmann 1962:30). In kort, Schweitzer se teologie en veral sy etiek is oudmodies en het reeds in die vergetelheid geraak (Cupitt 1999:61) want dit is onverdedigbaar en onprakties.

Oor die negatiewe kommentaar is twee opmerkings ter sake: (1) Bykans sonder uitsondering fokus die kritiek op geselekteerde uitsprake van Schweitzer. Daar word nie eintlik met die rykdom van sy werke as samehangend en verbandhoudend in gesprek getree nie. (2) Dit is nogal opvallend hoe dikwels die kritiek niks anders behels as beklemtoning van wat hy nie sê nie. Met ander woorde, Schweitzer is verkeerd want wat die verskillende kritici telkens verwag om te kry, is nie daar nie. ${ }^{7}$

Om Schweitzer te bestudeer het uitdagings. Hy beskou dit as 'n kenmerk van sy werk dat die grens tussen godsdienstige en filosofiese taal vaag is. ${ }^{8}$ Terugskouend is dit duidelik dat Schweitzer dit deel van sy lewenstaak geag het om die diskoerse van filosofie en teologie met mekaar te verweef. Uiteraard kan só 'n styl van beredenering ook verwarring skep.

\subsection{Temas wat die huidige teologiese diskoers kan verryk}

Oënskynlike teenstrydighede noop mens om dieper te delf. In Schweitzer se werke vind ons 'n denker wat doelbewus wil redelik wees, sonder om enigsins die belang en rol van geestelikheid of mistiek te ontken. In talle van sy argumente is daar geen verwysings na God nie, maar in ander maak hy verskeie aansprake op Christus en die Heilige Gees. Daar is 'n swaar beklemtoning van die probleem wat betref die aard van kultuur en die nodigheid om beskawing te verbeter, maar tegelykertyd verwag Schweitzer ook eerbied vir die geringste vorme van lewe. Hy sien 'n verband tussen die belangrike politieke uitdagings van sy tyd en die groei wat nodig is in gemeenskappe se geestelike lewens. Soos Macquarrie (1971:145) tereg opmerk, "he is ... a considerable religious thinker, and his views deserve a respectful hearing if for no other reason than that he has lived them out" - iets wat bitter min van ons regkry. Schweitzer se siening van hoekom ons

7 Daar is ook deeglike studies van Schweitzer wat die probleme met sy werk toelig, t.w. Clark (1962), Martin (2007), Rud (2011), Goodin (2013).

8 'n Opmerking in 'n brief aan Oskar Kraus, gedateer 2 Mei 1926 (Schweitzer 2006:439). 
dikwels faal, en hoe om etiese kongruensie te bereik, is genoeg rede om sy werk ernstig op te neem.

Daar is voldoende grond om opnuut erns te maak met Schweitzer se denke, om, in die woorde van Barsam (2008:xiii), deel te neem aan "the new quest for Schweitzer". Vir die doeleindes van hierdie artikel fokus ek op drie temas. ${ }^{9}$ Eerstens word die kwessie van 'n "nuwe" godsdiens bespreek. Schweitzer dink dit is 'n fout om te begin met die probleem van hoe mens denke met die werklikheid realisties en betroubaar met mekaar in verband bring. Die kenteoretiese vraagstukke en praktiese uitlewing van teologiese oortuigings moet syns insiens nie begin met 'n dualisme of teenstelling nie, maar met die verweefdheid van werklikheid en geloof, met wat hy noem etiese mistiek. Dit is in die lig hiervan wat die rol van wil-tot-lewe bekyk word, en ook aandag gegee word aan Schweitzer se etiek van liefde.

Die tweede tema behels die sentraliteit van lewe. "Lewe" het besondere betekenis in Schweitzer se denke - dikwels meer as net biologiese lewe en "eerbied vir die lewe" is nie net 'n beginsel of kriterium nie. Dit is meer soos 'n perspektief, dalk selfs 'n metafisika, 'n hermeneutiese program waarmee en waarbinne geleef moet word. Die kwessie van lewensbeaming (Lebensbejahung) word bespreek alvorens eerbied vir lewe ontleed word.

Derdens word "verantwoordelikheid" ter sprake gebring. Hieronder word wat Schweitzer sy "ander gedagte" genoem het, saamgevat. Eerbied vir lewe beteken, volgens Schweitzer, dat voorspoed en geluk 'n mens tot verantwoording roep. Mens se gewete en emosies noop jou om verantwoordelikheid te aanvaar vir ander lewe wat nie kan voluit lewe nie. Dankbaarheid, 'n manifestasie van die wil-tot-lewe, bring mens daartoe om lewe, ander se lewens, te eerbiedig en te láát lewe.

\section{Etiese mistiek}

Schweitzer gebruik die term "etiese mistiek" ("ethische Mystik") om die onlosmaaklike verweefdheid van moraliteit met die geestelike aan te

9 Uiteraard kan ander Schweitzeriaanse temas aangedui word. Daar is 'n merkwaardige oplewing in belangstelling in Schweitzer se bydrae tot 'n biosentriese etiese teorie en veral in die moontlikhede vir die hantering van die ekologiese krisis (Callicott 1986; Johnson 1991:134-141; DesJardins 1993:147-151; Günzler \& Lenk 2005). 
dui. "Mysticism must never be thought to exist for its own sake. ... Such a mysticism is not the friend of ethics but a foe. Mysticism which exists for itself alone is the salt which has lost its savor" (Schweitzer 1959:304). Mistisisme verwys na die oortuiging dat kontak met die goddelike moontlik is, 'n innerlike belewing wat nie noodwendig iets te doen het met die eksterne wêreld nie - en vir Schweitzer is dit problematies. "Of all the mysticism of the past it must be said that its ethical content is slight. It puts men on the road of inwardness, but not on that of a viable ethic" (Schweitzer 1933:232). Etiese mistiek lei na aktiewe betrokkenheid in die wêreld, en presies as etiese werksaamheid word eenwording met onbegrensde bestaan (das unendliche Sein) moontlik. Schweitzer herinterpreteer die doel van mistisisme: dit behoort 'n hoër etiese bewussyn te genereer wanneer daar eenheid is met die goddelike. Maar dan kom die etiese nie na die mistiese nie, of volg mettertyd na mistiese eenwording nie. Die mistiese belewing behels die etiese optrede.

Schweitzer se retoriek vertoon hier en daar kenmerke van mistisisme, maar mens sal vergeefs soek na beskrywings van mistiese ervarings. Sy werk is gerig op die rol van mistiek in moraliteit en in die samelewing. Sy mistiek verwys nie na die individu se belewenis soos wat gebed en meditasie bewussyn beïnvloed nie; die ervarings wat hy beskryf verwys na die integrering van werk en doen met innerlike oortuiging en pligsbesef. Etiese mistiek verwys na die aktiewe verhouding waarin 'n mens met ander lewe. Eenheid met die goddelike word moontlik deur interaksie met lewe.

'n Aktiewe, eties-begronde mistiek vermy die probleme van passiwiteit en innerlikheid (insigself-gerigtheid) wat dikwels kenmerkend is van mistici. Schweitzer verwerp panteïstiese en monistiese eenwording van die mens met God. Monisme beteken vir hom die verlies van bewus-wees van die werklikheid want dit behels 'n samesmelting sonder onderskeid of voorwaarde met die goddelike. Die groot gevaar met sulke samesmeltings is dat dit 'n doel in sigself raak, en passiwiteit aanmoedig. Die "highest manifestation of spirituality" is nie passiewe harmonie met die goddelike nie, maar "ethical existence" (Schweitzer 1953:297). ${ }^{10}$

10 "Zu einer Geistigkeit, die ethisch ist, und zu einer Ethik, die alle Geistigkeit in sich schließt, müssen wir uns erheben. Dann erst werden wir in tiefer Weise lebenstüchtig" (Schweitzer 1923b:371). 
Mistisisme is dus slegs van waarde in soverre dit eties is. ${ }^{11}$ Schweitzer verwerp enige vorm van spiritualiteit wat nie uitloop op konkrete handelinge nie: die "ethical, living God cannot be found in the contemplation of the world" (Schweitzer 1939:84), en ook nie in denke alleen nie; deelname aan die gemeenskap van die lewe laat 'n band met die goddelike tot stand kom. Geloof moet gestut word nie met 'n teorie van intellektuele analise nie, maar deur praktyk. Mense moet 'n mistiek vind wat etiese aksie aanspoor en dan daardeur versterk word; en 'n etiek wat steun op mistieke ervaring en verryk word daardeur:

It is only through the manifestations of Being, and only through those with which I enter into relations, that my being has any intercourse with infinite Being. The devotion of my being to infinite Being means devotion of my being to all the manifestations of Being which need my devotion, and to which I am able to devote myself.

Only an infinitely small part of infinite Being comes within my range ... But by devoting myself to that which comes within my sphere of influence and needs me, I make spiritual, inward devotion to infinite Being a reality (Schweitzer 1959:305).

Hierdie "Erscheinungen des Seins [manifestations of Being]" is die verskillende vorme van lewe - in die volste sin van die woord - in die wêreld. Kortliks gestel: slegs deur (eties begronde) interaksie met ander lewe kan mens 'n band met die goddelike handhaaf. ${ }^{12}$

Die basis vir Schweitzer se "gelykstelling" van mistiek en sedes, die bewysgrond van etiese mistiek, vind ons in die konsep wil-tot-lewe.

11 "Ihrerseits ist Mystik wertvolle Welt- und Lebensanschauung nur in dem Maße, als sie ethisch ist” (Schweitzer 1923b:369)

12 Daar is twee besondere elemente in dié vorm van mistiek wat onderstreep moet word: (1) daar is nie 'n antitese van Skepper teenoor lewe nie, eerder die moontlikheid van 'n Ich und $D u$ verhouding met eenwording én differensiasie (om dit met Buber (1958) te verduidelik. Die vertrekpunt is die Skepper wat nie net geskep het nie maar tegelyk ook sigbaar gemaak word deur die skepping wat menslike deelname daarin wil hê. (2) Andersyds word 'n inter-afhanklike verwantskap tussen mense, nie-menslike lewe en oneindige syn gehandhaaf; 'n mistisisme wat nie net'n geestelike eindpunt het nie maar eerder ondersteunende verbintenisse wil verwesenlik, 'n etiese doel. 


\subsection{Die wil tot lewe}

"Wille zum Leben" is 'n sleutelbegrip in Schweitzer se filosofie/teologie. "The essential thing to realize about ethics is that it is the very manifestation of our will-to-live" (Schweitzer 1936c:155). Omdat mistiese eenheid in die wil plaasvind, is dit die wil-tot-lewe wat tot uiting kom in eerbied vir lewe.

Hierdie "wil" moet verstaan word teen die agtergrond van Westerse denkstrome sedert antieke tye. Daarvolgens word die wil beskou as dit wat dit moontlik maak om te reageer op die onbekende (soos transendente aansprake), sonder intellektuele ontleding, maar wat ook anders is as sensuele, irrasionele emosie (vgl Dihle 1982:123, 127). Arthur Shopenhauer, wat 'n groot invloed op Schweitzer uitgeoefen het, ${ }^{13}$ betoog dat die "wil" deur die hele natuur bestaan. Volgens Schopenhauer is ons bewus van onsself op twee duidelik onderskeibare wyses: 'n kognitiewe manier waardeur ons eksterne dinge ontdek, maar ook 'n innerlike manier wat as wil beskryf kan word:

The first step in the fundamental knowledge of my metaphysics is that the will we find within us does not, as philosophy previously assumed, proceed first of all from knowledge; that it is not, in fact, a mere modification of knowledge, and thus something secondary, derived, and like knowledge itself, conditioned by the brain; but that it is the prius of knowledge, the kernel of our true being. The will is that primary and original force ... and expresses in itself in some way everything in the world and is the kernel of all phenomena (Schopenhauer 1966a 2:293).

Hierdie voorrang van die wil kan verder omskryf word as die wil-tot-lewe.

Every glance of the world ... confirms and establishes that the willto-live, far from being an arbitrary hypostasis or even an empty expression, is the only true description of the world's innermost nature. Everything presses and pushes towards existence, if possible towards organic existence, i.e., life, and then to the highest possible degree thereof (Schopenhauer 1966a 2:350).

13 Sien o.a. Schweitzer 1959:235-248. Oor die impak van Schopenhauer op Schweitzer: Clark 1962:21-25; Goodin, D. K. 2013:40-57; Botha 2015. Die raamwerk vir Schopenhauer se invloed is natuurlik die Kantiaanse filosofie; Schweitzer het sy eerste proefskrif oor Kant geskryf (Schweitzer 1899), en in bykans al sy geskrifte is daar verwysings na Kant. 
Schweitzer eien hierdie gebruik van wil-tot-lewe in sy werk. Die wil-totlewe is nie iets sekondêr nie (dit volg nie vanuit kennis van die lewe nie), dit is primêr, onmiddellik en onvoorwaardelik (Schweitzer 1959:55), en daarom is die wil-tot-lewe die beginpunt vir filosofiese ondersoek: "the essence of things-in-themselves, which is to be accepted as underlying all phenomena," is die "will-to-live" (Schweitzer 1959:236-237). ${ }^{14}$

Gevolglik kom Schweitzer tot die gevolgtrekking dat die wil-tot-lewe alles beslissend is:

In everything that exists there is at work an imaginative force, which is determined by ideals. In us beings who can move about freely and are capable of pre-considered, purposive activity, the craving for perfection is given in such a way that we aim at raising to their highest material and spiritual value both ourselves and every existing thing which is open to our influence.

The highest knowledge, then, is to know that I must be true to the will-to-live. ... To live out one's life in the direction of its course, to raise it to higher power, and to ennoble it, is natural (Schweitzer 1959:282).

Schweitzer skryf dat "philosophizing means experiencing our consciousness as an emanation of the creative impulse which rules in the world" (Schweitzer 1959:264-265). Die wil-tot-lewe is ingeweef in die "materiaal" van bestaan, die sine qua non van lewe. 'n Mens se selfbelewenis is die gevolg van die ervaring van die wil-tot-lewe; alle lewe, nie net mense nie, ervaar die wil-tot-lewe (Schweitzer 1959:308). Dit wil sê, mens se selfinsig is tegelykertyd ook 'n venster wat oopmaak op die aard van die werklikheid. Schweitzer se metafisika is bykans vitalisties: ten spyte van die diversiteit en veelvoudigheid van lewe op aarde, is daar 'n onderliggende essensie, die wil-tot-lewe.

In hierdie "metafisika” van die wil, sien Schweitzer'n besondere element. Hy verwerp Schopenhauer se oortuiging dat "everything which helps to deaden the will-to-live is good" (Schopenhauer 1966b 1:362; vgl met Schweitzer 1959:241). Terwyl Schopenhauer oor die wêreld en die lewe sê dat "we

14 Dit is in dialoog met Kant wat Schopenhauer beklemtoon die Ding-an-sich is die Wille zum Leben (Schopenhauer 1966a 2:14, 16, 18). 
have not to be pleased but rather sorry about the existence of the world; ... its non-existence would be preferable to its existence; ... it is something which at bottom ought not be..." (Schopenhauer 1966a 2:576), sê Schweitzer (1936b:4) dit is die bose wat genegeer moet word. Om die wil-tot-lewe om te keer na 'n wil-tot-nie-lewe-nie soos wat Schopenhauer doen, behels 'n weerspreking, 'n wil wat nie wil nie (Schweitzer 1936b:7; 1959:280). Net om so iets te sê moet daar 'n alreeds 'n liggaam wees wat wil leef; die uitspreek (van lewensontkenning) word weerlê deur die liggaam wat dit sê.

Erkenning en bevestiging van die wil-tot-lewe ("Lebensbejahung") is instinktief en natuurlik, dit dryf mens om lewe te onderhou.

The essential nature of the will-to-live is determination to live itself to the full. It carries within it the impulse [Drang] to realize itself in the highest possible perfection. ... How this striving [Streben] originated in us, and how it has developed, we do not know, but it is given with our existence (Schweitzer 1959:282).

Die strewe om lewe te bewaar en te "verhoog" ("raising to their highest material and spiritual value") is presies die wil-tot-lewe: die oorwinning oor die pessimistiese feite van kennis en die begin van eerbied vir lewe (cf. Schweitzer 1959:279).

Kenteoreties beskou skuif Schweitzer van Kant na Schopenhauer. ${ }^{15}$ Schweitzer probeer nie die kloof tussen die ding-in-sigself en die voorstelling daarvan verhelder (of oorkom) nie; hy wil daardie onderskeid vermy deur die ding-in-sigself kenbaar te beskou as gevolg van die wil-tot-lewe. Omdat die wil-tot-lewe in die dinge "daarbuite" is én in die kenner (die mens), bestaan die moontlikheid van kennis sonder voorstelling (m.a.w., voor of sonder uitdrukking in taal). Hy skryf dat gewaarwording van mens se eie wil (oftewel intuïsie) die gewaarwording van die ding-in-sigself behels.

The knowledge that I acquire from my will-to-live is richer than that which I win by observation of the world. ... The right course is to let the ideas, which are given in our will-to-live be accepted as the higher and decisive kind of knowledge. My knowledge of the world is knowledge from outside, and remains forever incomplete. The

15 Die moontlikhede van Schopenhauer se kenteoretiese klem op die wil-tot-lewe word deeglik uiteengesit deur Janaway (1989:117-207, 291-316) en Hamlyn (2000). 
knowledge derived from my will-to-live is direct, and takes me back to the mysterious movements of life as it is in itself. ... That is why it is so profoundly important ... that [we] be determined solely by what is given within (Schweitzer 1959:281-282, 285).

Etiese mistiek, die erkenning en uitlewing van die wil-tot-lewe te midde van lewe wat wil lewe is nie 'n "ingenious dogmatic formula" nie; dit behels 'n omvattende persoonlike opbenbaring: "In the universe, the will-to-live is a fact; in us, it is a revelation" (Schweitzer 1965:27).

Day by day, hour-by-hour, I live and move in it. At every moment of reflection it stands fresh before me. There bursts from it again and again as from roots that can never dry up, a living world- and life-view, which can deal with all the facts of Being. A mysticism of ethical union with Being grows out of it (Schweitzer 1959:309).

Die intuïtiewe, innerlike (en pre-rasionele) kant van Schweitzer se begrip, wil-tot-lewe, moet verbind word met sy ander uitsprake oor die "innerlike lewe". So beklemtoon Schweitzer, onder meer, dat musiek van kosmiese belang is (Schweitzer 1911 1:167). Musiek open dieptes van innerlikheid wat groei en selfverbetering (Selbstvervollkommnung) fasiliteer (vgl Schweitzer 1911 1:338-340). Ook om by tye stilte op te soek, maak geestelike groei moontlik. ${ }^{16}$

Die wil-tot-lewe is nie net 'n eienskap van mense nie. "Everything, accordingly, which meets me in the world of phenomena, is a manifestation of the will-to-live" (Schweitzer 1959:237, 282). Maar, by mense is die wiltot-lewe eties (Schweitzer 1936a:182).

In any case, no philosophy puts me in relationship to the universe on an ethical basis. ... Ethics alone can put me in true relationship with the universe by my serving it, co-operating with it; not by trying to understand it. This is why Kant is so profound when he speaks of practical reason. Only by serving every kind of life do I enter the service of that Creative Will whence all life emanates. I do not understand it; but I do know (and it is sufficient to live by) that by serving life, I serve the Creative Will. It is through community

16 Kyk Clark (1962:46-47) se opsomming van die aspek. 
of life, not community of thought that I abide in harmony with that Will. This is the mystical experience of ethics (Schweitzer 1936a:189).

Morele handelinge is die knooppunt vir die mistieke verhouding tot God en ander lewe: "... all Being is Life, and ... in loving self-devotion to other life we realise our spiritual union with infinite Being" (Schweitzer 1936b264). ${ }^{17}$

Die oneindige wil-tot-lewe, die allesomvattende wil-tot-lewe, oneindige Syn en die Kreatiewe Wil is Schweitzer se filosofiese terme vir God. Hy doen dit doelbewus:

Hitherto it has been my principle never to express in my philosophy more than I have experienced as a result of absolutely logical reflection [i.e., as a matter of philosophical deduction]. That is why I never speak in philosophy of "God" but only of the "universal Will-to- Live" which meets me in a twofold way: as Creative Will outside me, and Ethical Will within me. But if I speak the traditional language of religion, I use the word "God" in its historical definiteness and indefiniteness (in 'n brief gedateer 2 Januarie 1926; Kraus 1944:42; Schweitzer 2006:431).

Die omvang van die probleem, hoe die kognitiewe band of kontak met die onverwoorde werklikheid verband hou, kan nie hier ontleed word nie, en daar is nog steeds die vraag oor die kennende subjek wat sigself as objek (die subjek se wil-tot-lewe) neem, maar Schweitzer se klem op lewe is 'n gewigtige manier om 'n basis te bied aan 'n lewens- en wêreldbeskouing. Sy denke bied hier baie moontlikhede.

In besonder kan gewys word op die verskuiwing in denkraamwerk sodat mens en natuur nie as teenoor mekaar opgesteldes gesien word nie (Pantazis 2009).

\subsection{Etiek van liefde}

Etiek, volgens Schweitzer, is nie iets wat'n persoon by sy of haar gemeenskap kan leer nie. Ja, 'n gemeenskap behoort die elemente van moraliteit in wette

17 Die "wissende Unwissenheit der Mystik der Ethik" is kennis in soverre as wat dit "das eine, was wir im Bereiche dieses Gehemnisses wissen können und wissen müssen, weiß: daß nämlich alles Sein Leben ist und daß wir in liebender Hingabe an anderes Leben unser geistiges Eins-Werden mit dem unendlichen Sein verwirklichen" (Schweitzer 1935:662). 
en reëls te enkodeer, maar dit is nie ware etiek nie. Om te besluit oor wat reg en wat verkeerd is, is alleenlik moontlik vir die denkende individu (Schweitzer 1959:327-329). Wat is etiek?

Ethics is the maintaining of life at the highest point of development - my own life and other life - by devoting myself to it in help and love, and both these things are connected. And this ethics, profound, universal, has the significance of a religion. It is religion (Schweitzer 1934:83).

Etiek is liefde; die insig begin met die besef dat die idee van liefde 'n ligstraal is wat vanaf die Oneindige kom. Tog vind ons nie die God van liefde in die natuur nie, maar in sy bekendmaking aan ons in die wil-tot-liefde wanneer ons as etiese persoonlikhede verhoudings bou (Schweitzer 1933:240-241).

Die wil-tot-lewe en eerbied vir lewe is verbonde aan wat Schweitzer noem die wil-tot-liefde. "What shall be my attitude toward this other life which I see around me? It can only be a piece of my attitude toward my own life. If I am a thinking being, I must regard other life than my own with equal reverence" (Schweitzer 1936a:185). Maar die wil-tot-lewe wat nie begelei word deur 'n wil-tot-liefde nie word 'n wil-tot-mag (Nietzsche se Wille zur $\left.\operatorname{Macht}^{18}\right)$.

Die bron vir Schweitzer se verstaan hiervan is Jesus van Nasaret. Jesus beliggaam liefde as barmhartige toewyding aan ander mense, en eerbied vir lewe is Jesus se liefdesetiek uitgebrei na alle lewe. "The ethic of reverence

18 Nietzsche daag Schopenhauer (en sodoende ook Schweitzer) uit oor die siening dat die wil-tot-lewe die grond is vir alle syn; hy beskou dit as naïef. Die wil-tot-mag is die impuls wat lewe onderlê: "This world is the will to power - and nothing besides! And you yourselves are also this will to power - and nothing besides!". (Nietzsche 1968:550 [\$1067], 333, 366, 369) Nietzsche is nie ligvoetig hieroor nie: "Life itself is essentially appropriation, injury, overpowering of the alien and weaker; suppression, hardness, imposition of one's own forms, incorporation and at the least, at it mildest, exploitation ... [the will to power] will strive to grow, spread, seize, become predominant not from any morality or immorality but because it is living and because life simply is will to power" (Nietzsche 1966:259).

Schweitzer erken geredelik die invloed van Nietzsche se filosofie van die lewe op sy eie denke (Schweitzer 1992:336-337), maar slaan 'n ander weg in met die klem op wil-tot-liefde. Schweitzer kritiseer Nietzsche vir sy veronderstelling dat die geestelike en natuurlike antagonisties is, dat sy individualisme noodwendig op brutale gedrag moet uitloop en dat Nietzsche se eie lewe nie sy lewensbevestigende etiek weerspieël nie (Schweitzer 1959:245-249). 
for life is the ethic of love widened into universality. It is the ethic of Jesus, now recognized as a logical consequence of thought" (Schweitzer 1933:235).

Die invloed van Jesus op Schweitzer kan beswaarlik duideliker gesien word as in die rol wat hy aan die wil-tot-liefde toeken. Eerbied is nie 'n noodwendigheid van die wil-tot-lewe nie, maar wel van die wil-tot-liefde. Schweitzer se Kulturphilosophie moet saam met sy Nuwe-Testamentiese werke verstaan word. 'n Verhouding met Christus is 'n verbintenis tussen menslike wil en goddelike wil: "In reality He [Jesus] is an authority for us, not in the sphere of knowledge, but only in the realm of the will" (Schweitzer 1913b:197). Die ware verstaan van Jesus is om te begryp hoe die liefdes-wil inwerk op menslike wil en die erkenning dat dit gehoorsaamheid aan Jesus se wil behels. ${ }^{19}$

Dit is Jesus se invloed (Schweitzer gebruik die woord rôle) wat verseker dat die menslike wil-tot-lewe nie buitensporig voortwoed nie (met ander woorde, dat dit nie bloot wil-tot-mag is nie), sodat solidariteit met ander moontlik is. Die wil-tot-liefde stuur ons menslike wil nie daarna om ander lewe te oorheers nie, maar na eerbied; dit stimuleer menslike wil om ondersoek in te stel hoe daar erkenning en ondersteuning aan ander gebring kan word:

... in whatever state of life [one] finds [oneself], the ethics of reverence for life do this: they force [one] without cessation to be concerned at heart with all the human destinies and all the other life-destinies which are going through their life-course around one, and to give oneself, as human, to the one who needs a fellow-human. ... [The ethics of reverence for life] demand from all that they devote a portion of their life to their fellows. In what way and to what extent this is prescribed for one, the individual must gather from the thoughts which arise in one, and from the destinies among which one's life moves. ... But one with another we have all to recognize that our existence reaches its true value only when we experience in ourselves something of the truth of the saying: 'He that loseth his life shall find it' (Schweitzer 1959:323).

19 "Das wahre Verstehen Jesu is das von Wille zu Wille. Das wahre Verhältnis zu ihm is das des Ergriffenseins von ihm. Alle christliche Frömmigkeit is nur so viel wert, als in ihr Hingabe unseres Willens an den seinen statthat" (Schweitzer 1931a:73) 
Vir Schweitzer is eerbied vir lewe 'n noodwendige afleiding wat volg vanuit die erkenning van die wil-tot-lewe en die ontmoeting met die wil-tot-Liefde (Jesus van Nasaret). In talle van sy preke beklemtoon hy die vernuwing, oftewel transformasie, wat die blote wil-tot-lewe ondergaan wanneer toewyding aan ander mense en ander lewe plaasvind (bv. Schweitzer 1969:50-57, 58-66, 118-119). Schweitzer se etiek van eerbied vir lewe, sy etiese mistiek het 'n teologiese onderbou, 'n Christologiese komponent waarsonder dit nie kan sin maak nie.

Die wil-tot-liefde is vir Schweitzer'n manier om oor Jesus se teenwoordigheid te praat; dit word steeds voortdurend sigbaar in die verloop van die geskiedenis. In 'n brief praat hy van die Gees as "God's voice of love speaking to ... our hearts" (kyk Hagedorn 1948:137). In die Gees is die wil van God nie meer buitekant nie; die wil-tot-liefde word werklikheid binne mens: "Through the Spirit they [gelowiges] feel in their hearts love" (Schweitzer 1953:303).

Die "werking" van die Gees is egter nie 'n magiese wondermiddel wat misterieus sommiges tref en ander nie. Daar is 'n betekenisvolheid aan Schweitzer se vermyding van teologiese taal. Hy benadruk dat etiese ingesteldheid deel is van menswees, gegewe met ons bestaan. Die wil-totlewe is die moontlikheid van etiek (Schweitzer 1959:77, 332). Vir 'n mens om te verander behels 'n proses, 'n aktiewe reeks handelinge en die Gees se bydrae is presies daardie pogings wat mense aanpak. Schweitzer beskou diens aan ander se lewens as die impuls van en die ooreenstemming met die wil-tot-liefde waardeur die goddelike wil geïnternaliseer word. Die energie wat etiese optrede moontlik mak is die etiese wil se ondersteuning van lewe.

\section{Lewe is sentraal}

Schweitzer is nie die eerste (of enigste) filosoof/teoloog wat liefde en solidariteit tussen mense en ander lewensvorme bepleit nie. Hy doen dit egter op 'n merkwaardige wyse en sy betoog het 'n veelkantigheid en omvang wat beslis aandag verdien. Dit is hierdie erns met lewe wat sy studies oor wêreldgodsdienste (en die verhouding van die Christendom met ander godsdienste) aangespoor het, en alhoewel die studies van sy meer problematiese besprekings bevat, is dit duidelik dat hy diep beïndruk 
was met ahimsa, geweldloosheid en vermyding van leed aandoen, die kern van Jaïnisme: "The laying down of the commandment not to kill and not to damage is one of the greatest events in the spiritual history of mankind" (Schweitzer 1936b:82-83). Maar vir Schweitzer behels "lewe" veel meer as net beskerming en bewaring van lewe: "I am life which wills to live, in the midst of life which wills to live" (Schweitzer 1933:156).

\subsection{Lewensbeaming}

Die regte ingesteldheid teenoor lewe moet met 'n bevestiging begin. Lewensbevestiging vir Schweitzer

... conveys more than mere 'acceptance'. It implies ratification or confirmation by the affirming person. The affirmer of world and life is [the one] who says, 'Yes!' to the existence of the whole creation and one's existence in it. [One] need not be entirely happy with the details of the created world or the details of [one's] own existence ... [One] believes that 'life is worth living,' ... (Clark 1962:29)

Sodanige lewensbevestiging is 'n erkenning van die intrinsieke waarde van alle lewe. Etiese lewens- en wêreldbevestiging is die aktiewe pogings om alle lewensvorme in die wêreld te help om te floreer. Die individu wat etiese lewenserkenning aanvaar, streef daarna om medemense, die gemeenskap, die nasie, die mensdom en ten slotte alle lewe te dien ("und überhaupt allem Leben in höchstem Wollen und Hoffen zu dienen”, Schweitzer 1935:431-432).

Vir Schweitzer is 'n lewensbeskouing (Lebensanschauung) uitdrukking van dit waarmee mens sin vind en sin gee aan die lewe; dit wat 'n mens se nadenke oor die aard en doel van die skepping en mense se rol daarin verwoord. Tradisioneel het die Westerse filosofie voorrang gegee aan wêreldbeeld:

To understand the meaning of the whole - and that is what a worldview demands! - is for us impossibility. I believe I am the first among Western thinkers ... to be absolutely sceptical about our knowledge of the world without simultaneously renouncing belief in world- and life-affirmation and ethics (Schweitzer 1959:76).

Schweitzer dink dit is onmoontlik dat kennis van die wêreld op 'n etiek sal uitloop. Die korrekte beginpunt is 'n docta ignorantia, 'n verligte onkunde wat geredelik toegee hoe "ultimately mysterious and unfathomable the world 
and life are" (Schweitzer 1936:263-264). Hierdie verligte insig se eerste stap is berustende oorgawe (Hingebung): 'n aanvaarding wat die begeerte om die heelal of God volledig te wil ken prysgee. "Our self-devotion to life with a view to furthering it and maintaining it at its highest value constitutes active union with the eternal Being, completing the union in thought which consists in resignation to what happens in the Universe" (Schweitzer 1936b:260). Opvattings oor die lewe en die wêreld moet saamgestel word uit die oortuigings wat in ons wil-tot-lewe te vinde is, en daarom is Schweitzer kenteoreties skepties oor kennis wat poog om die werklikheid te verstaan sonder 'n volledige bevestiging van die waarde van lewe. 'n Fondament vir etiek is nie te vinde in die natuurwette of dierewêreld nie.

Nature knows no reverence for life. It produces life in thousands of the most meaningful ways and destroys it in thousands of the most senseless ways. Creatures live at the cost of the lives of other creatures. Nature allows them to commit the most terrible cruelties. Nature is beautiful and sublime, viewed from the outside. But to read in its book is horrible. And its cruelty is so senseless! (Schweitzer 1986:15-16)

The world is a ghastly drama of the will-to-live divided against itself. One existence makes its way at the cost of another; one destroys the other. One will-to-live merely exerts its will against the other, and has no knowledge of it. But in me the will-to-live has come to know about other wills-to-live (Schweitzer 1959:312).

The solution is, not to try to get rid of dualism from the world, but to realize that it can no longer do us any harm. This is possible, if we leave behind us all the artifices and inveracities of thought and bow to the fact that, as we cannot harmonize our life-view and our world-view, we must make up our minds to put the former above the latter. The volition [Wollen], which is given in our will-to-live, reaches beyond our knowledge of the world. What is decisive for our life-view is not our knowledge of the world but the certainty of the volition, which is given in our will-to live (Schweitzer 1959:78).

Dit volg dus dat etiek voortvloei vanuit 'n lewensbeskouing. Die kennis wat mens innerlik verken oortref dit wat mens uitwaarts in die wêreld ontdek: "I can understand the nature of the living being outside of myself only through the living being within me ... Knowledge of [external] reality must 
pass through a phase of thinking about the nature of [personal] being" (Schweitzer 1933:104).

Selfinsig lei na kennis van die werklikheid. Die sleutel wat wêreldverstaan ontsluit is betekenisvolle selfverstaan. ${ }^{20}$ Hierdie aanspraak van Schweitzer is 'n argument volgens analogiese afleiding: die verskynsel dat selfbewussyn oorgaan in abstrakte kennis is soortgelyk aan die wil-tot-lewe wat in die wêreld lewe in sy kompleksiteit stu (Schweitzer 1959:281-283). Vanuit hierdie perspektief is al wat nodig is om te weet dat die werklikheid die wil-tot-lewe is: "... the most immediate and comprehensive fact of consciousness ... [is] 'I am life which wills to live, in the midst of life which wills to live”" (Schweitzer 1959:309).

\subsection{Eerbied vir lewe}

Dit is ironies dat die een saak waarvoor Schweitzer die meeste onthou word dikwels verkeerd verstaan word. In 'n mate het Schweitzer self bygedra tot die siening dat eerbied vir lewe naïewe, idealistiese en onpraktiese gedrag weerspieël, met taal soos die volgende:

If he walks on the road after a shower and sees an earthworm which has strayed on to it, he bethinks himself that it must get dried up in the sun, if it does not return soon enough to ground into which it can burrow, so he lifts it from the deadly stone surface, and puts it on grass. If he comes across an insect, which has fallen into a puddle, he stops a moment in order to hold out a leaf or a stalk on which it can save itself (Schweitzer 1959:310).

Eerbied vir lewe is egter allermins 'n romantiese veredeling van die natuur. Omdat dit eerstens 'n uitdrukking is van etiese mistiek, is blote beskerming van ander lewe nog glad nie eerbied nie. Etiese mistiek veronderstel 'n kosmiese dimensie:

Only a complete ethic has mystical significance. An ethical system, which is only concerned with the attitude of man to his fellow man and to society cannot really be in harmony with a world-view. It has

20 Dit is duidelik dat Schweitzer met Schopenhauer se filosofie die Kantiaanse kennisproblematiek herskryf. Vgl Schopenhauer se "revolutionary principle": "from yourself you are to understand nature, not yourself from nature” (Schopenhauer 1988:466). Kyk verder Schopenhauer 1966b:104-105. 
no relationship with the Universe.... Only when ethics embrace the whole Universe is an ethical world-view really possible. And then only does it become apparent that the ethical worldview is ethical mysticism (Schweitzer 1936b:259-260).

Eerbied vir lewe is 'n volledige etiek - dit is die bedoeling van Schweitzer se gebruik van die woord absolut. Heel Kantiaans sien Schweitzer eerbied vir lewe as 'n soort universele beginsel, in die trant van die kategoriese imperatief. Omstandighede kan nie die geldigheid van die lewensbeginsel ondergrawe nie. Eerbied vir lewe is nie 'n relatiwistiese etiek nie en dit kan nooit 'n stel reëls vir die indiwidu wees nie. Dit kan nie in detail beskrywe word nie en ook nie gereduseer word tot 'n formule nie. Sy definisie is 'n eenvoudige stelling: "It is good to maintain and to encourage life, it is bad to destroy life or obstruct it" (Schweitzer 1959:309). Hierdie omskrywing word wel deur hom toegelig met enkele voorbeelde, maar hy bied glad nie reëls aan nie en vermy om tegnieke te ontleed om uit te werk watter optredes van die eerbiedige mens verwag word.

An absolute ethic calls for the creating of perfection in this life. It cannot be completely achieved; but that fact does not really matter. In this sense, reverence for life is an absolute ethic. It does not lay down specific rules for each possible situation. It simply tells us that we are responsible for the lives about us. It does not set either maximum or minimum limits to what we must do (Schweitzer 1936a:187).

Al die lewensvorme rondom mens moet erken word. Eerbied vir lewe kan nooit net tot mense beperk word nie: "Ethics are responsibility without limit towards all that lives" (Schweitzer 1959:311). Die belang en uitdaging van hierdie aspek vir ons kontemporêre situasie kan nouliks oorbeklemtoon word.

A human is truly ethical only when one obeys the compulsion to help all life, which one is able to assist, and shrinks from injuring anything that lives. One does not ask how far this or that life deserves one's sympathy as being valuable, nor beyond that, whether and to what degree it is capable of feeling. Every life is sacred ... (Schweitzer 1959:310).

Hierdie lewens-beaming erken die intrinsieke waarde van alle lewe (Schweitzer 1959:57); "the mystery of life is always too profound for us, and its value is beyond our capacity to estimate" (Schweitzer 1936a:188). 
Dat menslike lewe noodwendig moet voorkeur ontvang is een van die denkfoute van tradisionele sedelere, aldus Schweitzer. In die praktyk moet mens noodgedwonge besluite neem oor die relatiewe prioriteit van verskillende lewensvorme, maar sulke oordele is uit-en-uit subjektief en die antroposentriese perspektief van sulke besluite sê niks oor die objektiewe (of realistiese) waarde van ander lewensvorme nie.

The ethics of reverence for life makes no distinction between higher and lower, more precious and less precious lives. It has good reasons for this omission. For what are we doing, when we establish hard and fast gradations in value between living organisms, but judging them in relation to ourselves, by whether they seem to stand closer to us or farther from us. This is a wholly subjective standard. How can we know the importance other living organisms have in them and in terms of the universe? (Schweitzer 1965:47)

Eerbied vir lewe is logies ('n "necessity of thought") en 'n innerlike noodwendigheid vir enigiemand wat besef dat sy of hy deel is van die wiltot-lewe (Schweitzer 1933:153).

Wanneer etiese besluite gevel moet word, sal dit altyd 'n subjektiewe besluit wees. Enige keuse vir die behoud van een deur die vernietiging (of beskadiging) van ander lewe is vasgevang in 'n oneerbiedige daad; die spanning sal nie opgelos word deur dit 'n "relatiewe" besluit te noem nie. Elke keer wanneer lewe opgeoffer word (of ingeperk word), hetsy "for the sake of maintaining [one's] own existence or welfare" of "for the sake of maintaining a greater number of other existences or their welfare," beweeg mens nie meer ten volle in die sfeer van die etiese nie (Schweitzer 1959:325).

Alhoewel hy die onbegrensde eise van eerbied vir lewe beklemtoon, is Schweitzer nie 'n voorstander van die onaantasbaarheid van die lewe nie. Dit gaan oor eerbied vir lewe. "Ehrfurcht" dra 'n grondtoon van ontsag en vrees; nie gehoorsaamheid aan 'n wet nie, maar "a mental attitude" (Gesinnung, Schweitzer 1959:344), "a new temper of mind" (Schweitzer 1959:83) wat die ontsluiting en verdere ontwikkeling van emosies, houdings en ingesteldheid van 'n mens se optrede bepaal. Eerbied is meer as 'n ideaal vir 'n mens se karakter, dit is 'n hoedanigheid, "being something which is ever present to thought, penetrates unceasingly and in all directions one's observation, reflection, and resolutions" (Schweitzer 1959:316). Eerbied vir 
lewe is nie soseer 'n etiek van beginsels as wat dit'n etos is nie: vorming van 'n ingesteldheid en opvattings onderliggend aan die besluite wat morele optrede bepaal.

\section{Lewe en verantwoordelikheid}

Eerbied vir lewe as 'n etiek-filosofie is die een groot bydraes van Schweitzer, maar hyself het opgemerk dat daarnaas 'n ander insig sy denke oorheers het: mens behoort voorspoed in die lewe nie as vanselfsprekend te beskou nie; voorspoed vereis 'n "dankoffer" in die vorm van ondersteuning of diens. ${ }^{21}$ As kind, vertel Schweitzer, het hy twee onuitwisbare ervarings beleef. Die eerste was die oorweldigende smart en lyding in die wêreld; die tweede die verontrusting oor "the right to good fortune [Glück]" soos wat hyself dit beleef het as 'n gelukkige kind wat in 'n bevoorregte en liefdevolle gesin groot geword het (Schweitzer 1924:60-62).

Hoe staan mens voor die twee kante van die werklikheid? Schweitzer se antwoord is, enersyds, met en in eerbied vir die lewe; andersyds, leef met die besef dat voorspoed verantwoordelikheid bring. Hy verduidelik die tweede aspek só:

No one has the right to take for granted one's own advantages over others in health, in talents, in ability, in success, in a happy childhood and congenial home conditions. One must pay a price for all these boons. What one owes in return is a special responsibility for other lives.

All through the world, there is a special league of those who have known anxiety and physical suffering. A mysterious bond connects those marked by pain. They know the terrible things [a human] can undergo; they know the longing to be free of pain. Those who have been liberated from pain ... must help alleviate the pain and anxiety of others, insofar as that lies within human powers. They must bring release to others as they received release.

21 "Ein anderer Gedanke, der mein Leben beherrscht ist der, dass wir das, was uns als Glück im Leben begegnet, nicht als etwas Selbstverständliches hinnehmen dürfen, sondern in irgend einem Helfen oder Dienen ein Dankbarkeitsopfer dafür bringen müssen" (in Jacobi 1971:228). 
[One] who has experienced good in one's life must feel the obligation to dedicate some of one's own life in order to alleviate suffering (Schweitzer 1965:40-41).

Om hierdie verantwoordelikheid te verstaan moet ons terugkeer na Schweitzer se beskrywing van wat gebeur wanneer etiese besluitneming plaasvind. Besluite oor lewe en lewens moet noodwendig kies tussen die etiese (meer lewe) en die nodige (minder lewe). Maar wanneer laasgenoemde gekies word, moet mens verantwoordelikheid vir daardie beskadiging en aantasting van lewe aanvaar. Skuld is 'n onontkombare kenmerk van lewe. "Whenever I injure life of any sort, I must be quite clear whether it is necessary" skryf Schweitzer: "Beyond the unavoidable, I must never go, not even with what seems insignificant" (Schweitzer 1959:318). Maar die onvermydelike bly: voortdurend is dit nodig om doelmatig te kies maar in die besluit vír wat geskik is om een lewe te behou ten koste van ander word mens skuldig, "guilty in some way or other through failure in reverence for life" (Schweitzer 1959:324).

Whenever I in any way sacrifice or injure life, I am not within the sphere of the ethical, but I become guilty, whether it be egoistically guilty for the sake of maintaining my own existence or werlfare, or unegoistically guilty for the sake of maintaining a greater number of other existences or their welfare (Schweitzer 1959:325).

Eerbied vir lewe, met ander woorde, bou skuld op: enersyds weens bevoorregting en voordeel wat mens altyd onverdiend toekom - voorspoed is nie vanselfsprekend nie en vereis kompensasie - maar ook andersyds deurdat mens voortdurend lewe moet inperk of uitskakel sodat sommige lewens kan voortgaan. Mens staan skuldig teenoor die lewe; óf weens onverdiende geluk, óf omdat die inperk van lewe toewyding aan 'n ander vereis.

Hierdie "ander gedagte" van Schweitzer is deel van hoé eerbied vir lewe as 'n lewensfilosofie (oftewel lewensbeskouing) in die praktyk uitwerk. Die een implikasie wat mens onmiddellik tref is die etiese egalitarisme: dit is 'n pleidooi vir sosiale gelykheid onder ongelykes, en spesifiek 'n oproep aan die wat kan om ongelykheid te verminder. 'n Tweede implikasie is dat dankbaarheid eintlik 'n trefwoord is van die eerbiedvolle lewe.

Die voorspoed (Glück) wat mens met verpligting laat, is wat Schweitzer betref nie net besittings nie, maar gunstige lewensomstandighede, gesondheid, 
die vermoë om te kan werk, 'n gelukkige ingesteldheid, selfs gesonde slaap (Schweitzer, in Jacobi 1971:228). Sy punt is nie 'n lysie waaraan sommiges voldoen nie, en hy beklemtoon dat 'n onvermydelike subjektiewe aspek aan die persepsie van "geluk" kleef. "Voorspoed" in hierdie sin gaan oor omstandighede wat voordelig is, omstandighede wat onverdiend en buite mens se keuses jou lewe bevorder - en daarin het dit wel 'n objektiewe basis. Schweitzer herinner ons: "Wir übersehen so viel, was uns als Glück zu Teil geworden ist, weil wir nicht nachdenklich genug sind über Glück" (in Jacobi 1971:228).

Hierdie anderer Gedanke van Schweitzer verwys dus na die verantwoordelikheid om met hulp en diens bevoorregting om te sit in meer gelykheid vir ander ("Entsprechendes im Dienen und Hingabe dafür zu leisten”). Gegewe die Kantiaanse ondertone in Schweitzer se denke sou mens selfs "verpligting" hier kon gebruik: voorspoed verplig mens om te help. Om voorregte en gawes te geniet word nie uitgesluit nie (Schweitzer self het immers akademiese en musikale ambisies nagestreef), maar die wil-tot-lewe eis dat daar een of ander tyd bestek geneem moet word, die balans moet herstel word, terugbetaling aan die wat nié so (onverdiend) bevoorreg is nie moet gedoen word.

Schweitzer verwys na diegene wat ly en swaarkry en dus geregtig is op hulp en bystand, maar wanneer ondersteuning dan plaasvind is dit die wil-totlewe wat opwel en die lewe wat so voortgaan maak dit moontlik om óók iets (hoe min ook al) "terug te betaal".

As Schweitzer verwys na "skuld" wat ophoop (wanneer noodwendig lewe geneem word om lewe te kan gee) is dit duidelik dat verantwoordelikheid ter sake is. In Duits kan Schuld beide "verskuldig aan" (debt) asook "skuldigheid" (guilt) beteken. Schweitzer kan nogal met sy retoriek op sy lesers se skuldgevoelens speel, maar hier bedoel hy dat die voordele van die lewe mens verskuldig maak aan die lewe. "Skuld", by wyse van spreke, verwys na die grootboek van lewensbevestiging en lewensnegering wat gebalanseer moet word. In Schweitzer se preke en briewe kan ons sien hoe hy poog om met self-reflektiewe nadenke aspekte van so 'n balans te vind, en dit dan probeer uitleef.

Moontlik kan hierdie "skuld" ook as dankbaarheid omskryf word, maar die tema van Schweitzer se insig is dat voorspoed verantwoordelikheid 
meebring; "good fortune obligates" (Spiegelberg 1975). Moraliteit is ingebed in diens aan ander; lewenskrag is 'n geleentheid vir die wil-tot-lewe om lewe te laat leef. Schweitzer is bewus daarvan dat dankbaarheid en voortdurende wederdiens in naasteliefde en eerbied vir lewe as 'n onoorkomelike berg van lewensskuld beskou kan word. Hy is baie prakties hieroor, en beklemtoon dat toewyding, bereidwilligheid, tyd, versorging van net diegene wat mens se lewensweg aanraak en beskeie hulpvaardigheid genoeg is om die skuld uit te wis. Mens moet help in soverre "as human power can and bring deliverance to others as one received deliverance ... Sooner or later the idea which I here put forward will conquer the world, for with inexorable logic it carries with it the intellect as well as the heart" (Schweitzer 1922:125-126).

Etiese mistiek ontken nie die werklikheid van bevoorregting en voorspoed nie, maar spoor aan tot liefdeshandelinge; dit behels dankbare verpligting om lewe te eerbiedig. Aksie volg vanuit die gewaarwording van bevoorregting.

\section{Samevatting}

In Schweitzer se oordeel faal die beskawing van sy tyd bitterlik om die verwoesting van menslikheid te voorkom. Die gangbare teologieë en filosofieë help niks om 'n etiese bewussyn te ontwikkel nie. Syns insiens moet daar herbesin word oor die grondslag vir moraliteit, 'n heroriëntering ten opsigte van die fundamentele mistastings van die Verligting moet plaasvind om die misplaaste vertroue op progressie en materiële vooruitgang teen te staan. Met eerbied vir die lewe diagnoseer Schweitzer nie net wat verkeerd geloop het nie; dit is 'n gewigtige, deurdagte lewensbeskouing waarmee 'n wêreldbeeld gebou kan word. Dit bied die grondslag vir "nuwe" benaderings.

Eerbied vir lewe, in Schweitzeriaanse strekking, betrek meer as etiek of 'n filosofie; dit het 'n godsdienstige karakter, en bevat "the surmising and the longings of all deep religiousness” (Schweitzer 1933:237; 1959:313).

Ons het hier 'n denkwyse wat, in Goodin (2007) se woorde "tailormade" is vir 'n huidige omgewingsetiek, wat van toepassing is in talle gedagtestromings rondom die ekologiese krisis, insluitende ekofeminisme en ekoteologie. Tegelykertyd bied dit moontlikhede vir denkrigtings wat ernstige, persoonlike oortuigings as deel van praktiese oplossings sien. Vir 
ons as Suid-Afrikaners wat worstel met die impak van verlammende en oorweldigende armoede het Schweitzer se etiek met die gepaardgaande voorspoed wat verantwoording eis verreikende belang.

Alhoewel Schweitzer onbeskroomd sy appel rig aan ons gewete, ons morele aanvoeling, herinner hy ons eintlik aan dit wat 'n persoon behoort te voel. Sy werk het die bedoeling om die morele sin aan te wakker; om dit wat gewoonlik dormant is, te aktiveer. Dit is dieselfde as wat die Bybelse profete en veral Jesus doen. Schweitzer neem nie net bloot die gesprek met morele filosofie op nie, maar streef doelbewus daarna om 'n nuwe, beter morele bewussyn aan die gang te kry. Hy gebruik hiervoor nie voorskrifte of reëls nie, maar aanmoediging, uitdagings, selfs verkondiging, maar veral aansporing. Hy wil mense lei en begelei deur woord en daad om te sien wat nodig is om te sien, om selfbegrip én werklikheidsinsig te bereik. Hy wil ons wys wat om van bewus te wees (die lewe), aanmoedig om daaroor te dink, herinner aan ons verantwoordelikheid, eis dat besluite geneem word, en dat alle lewe eerbiedig word.

Hoe geloof en etiek wedersyds mekaar bepaal is 'n vraag wat Schweitzer beskou het as deel van sý lewenstaak. Hierdie vraag is uiters aktueel in ons huidige konteks. Kan daar 'n kragtiger aansporing wees om ernstig oor Schweitzer se werk na te dink?

\section{Bibliografie}

Banning, W 1972. Typen van zedeleer: grepen uit de geschiedenis der niet in godsdienstig geloof gefundeerde ethiek. Revised by A van Biemen. Haarlem: De Erven F Bohn.

Barsam, Ara Paul 2008. Reverence for life: Albert Schweitzer's great contribution to ethical thought. Oxford: Oxford University Press.

Barth, Karl 1961. The doctrine of creation. Vol. 3.4 of Church dogmatics. Edinburgh: T \& T Clark.

- 1981. Ethics. Edited by D. Braun. Translated by GW Bromiley. Edinburgh: T \& T Clark.

Birch, Charles, and Cobb, John B Jr. 1981. The liberation of life: from the cell to the community. Cambridge: Cambridge University Press. 
Botha, Pieter JJ 1998. "History, Scripture and revelation: a conversation with Ferdinand Deist." Old Testament Essays 11, no. 3:386-414.

- 2015. "Eerbied vir die lewe: Albert Schweitzer se etiek as lewensfilosofie." LitNet Akademies 12, no. 2: 236-258.

Brunner, Emil 1947. The divine imperative: a study in Christian ethics. Translated by O Wyon. Philadelphia: Westminster Press.

Buber, Martin 1958. I and thou. 2d ed. Translated by RG Smith. New York: Charles Scribner’s Sons.

Buitendag, Johan 2004. "Günter Altner se jukstaponering van die denksisteme van Schweitzer en Darwin as resiproke korreksies.” Hervormde Teologiese Studies 60, no. 3:865-81.

Callicott, J Baird 1986. "On the intrinsic value of nonhuman species." In The preservation of species: the value of biological diversity, edited by BG Norton, 47-56. Princeton: Princeton University Press.

Clark, Henry 1962. The ethical mysticism of Albert Schweitzer: a study of the sources and significance of Schweitzer's philosophy of civilization. Boston: Beacon.

Craffert, PF 2003. "Mapping current South African Jesus research: the Schweitzerstrasse, the Wredebahn and cultural bundubashing." Religion \& Theology 10, no. 3:339-77.

Cullmann, O 1962. Christ and time. 2d ed. Translated by FV Filson. London: SCM Press.

- 1967. Salvation in history. Translated by FV Filson. London: SCM Press.

Cupitt, Don 1999. The new religion of life in everyday speech. London: SCM Press.

De Gruchy, John 2015. “Beyers Naudé: South Africa’s Bonhoeffer? Celebrating the centenary of the birth of Beyers Naudé 1915 - 2015.” Stellenbosch Theological Journal 1:79-98.

De Villiers, E 2003. "A Christian ethics of responsibility: does it provide an adequate theoretical framework for dealing with issues of public morality?" Scriptura 82:23-38.

DesJardins, Joseph R 1993. Environmental ethics: an introduction to environmental philosophy. Belmont: Wadsworth. 
Dihle, Albrecht 1982. The theory of will in classical antiquity. Berkeley: University of California Press.

Goodin, David K 2013. The new rationalism: Albert Schweitzer's philosophy of reverence for life. Montreal: McGill-Queen's University Press.

Goodin, David 2007. "Schweitzer reconsidered." Environmental Ethics 29, no. 4: 403-21.

Günzler, Claus and Lenk, Hans 2005. “Albert Schweitzer”: 1686-88.

In Encyclopedia of science, technology and ethics, edited by C.

Mitcham, 1686-88. Farmington Hills, MI: Macmillan Reference.

Hagedorn, Hermann 1948. Prophet in the wilderness: the story of Albert Schweitzer. New York: Macmillan.

Hamlyn, David 2000. "Schopenhauer and knowledge." In The Cambridge companion to Schopenhauer, edited by C Janaway, 44-62. Cambridge: Cambridge University Press.

Jacobi, Erwin R 1971. “Albert Schweitzer: 'Aus meinem Leben'. Ein unveröffentlicher Vortrag." Schweizer Monatshefte: Zeitschrift für Politik, Wirtschaft, Kultur 50: 224-31.

Janaway, Christopher. 1989. Self and world in Schopenhauer's philosophy. Oxford: Clarendon.

Johnson, Lawrence E 1991. A morally deep world: an essay on moral significance and environmental ethics. Cambridge: Cambridge University Press.

Kraus, Oskar 1944. Albert Schweitzer: his work and his philosophy. Edited by EG McCalman. London: Adam \& Charles Black.

Langfeldt, Gabriel 1960. Albert Schweitzer: a study of his philosophy of life. Trans. M Michael. New York: George Allen \& Unwin.

Macquarrie, J 1971. Twentieth-century religious thought: the frontiers of philosophy and theology, 1900 - 1970. London: SCM Press.

Martin, Mike W 2007. Albert Schweitzer's reverence for life: ethical idealism and self-realization. Aldershot: Ashgate. 
Mason, G 1994. "Ecological awareness through self-awareness: a dialogue between Albert Schweitzer's mystical concept of 'will-to-live' and general systems theory." In The relevance of theology for the 1990s, eds J Mouton and B Lategan, 501-10. Pretoria: Human Sciences Research Council.

Moltmann, Jürgen 1967. Theology of hope: on the ground and the implications of a Christian eschatology. Translated by James W Leitch. New York: Harper and Row, Harper Torchbooks/Library.

Nietzsche, Friedrich 1966. Beyond good and evil: prelude to a philosophy of the future. Translated by Walter Kaufmann. New York: Random House, Vintage.

- 1968. The will to power. Edited and translated by Walter Kaufmann. RJ Hollingdale. New York: Random House, Vintage.

Oliver, Erna 2006. "Afrikaner spirituality: a complex mixture." Hervormde Teologiese Studies 62, no. 4: 1469-87.

- 2010. "Afrikaner Christianity and the concept of empire." Verbum et Ecclesia 31, no. 1: 1-10.

Pantazis, Vasileios E 2009. "Reverence (Ehrfurcht) for the living world as the basic bioethical principle: anthropological-pedagogical approach." Ethics, Place and Environment 12, no. 2: 255-66.

Robinson, JM 1983. A new quest of the historical Jesus and other essays. Philadelphia: Fortress Press.

Rud, AG 2011. Albert Schweitzer's legacy for education: reverence for life. New York: Palgrave Macmillan.

Scheffler, E 1999. “Ernest Renan’s Jesus: An appraisal.” Neotestamentica 33, no. 1: 179-97.

Schopenhauer, Arthur 1966a. The world as will and representation. Vol. 2. Translated and edited by EFJ Payne. New York: Dover.

- 1966b. The world as will and representation. Vol. 1. Translated and edited by EFJ Payne. New York: Dover.

- 1988. Early manuscripts (1804-1818). Vol. 1 of Manuscript remains. Translated by EFJ Payne. Oxford: Berg.

Schweitzer, Albert 1899. Die Religionsphilosophie Kants von der "Kritik der reinen Vernunft" bis zur "Religion innerhalb der Grenzen der bloßen Vernunft”. Tübingen: J. C. B. Mohr (Paul Siebeck). 
- [1911] 1923. JS Bach. Vol. 1. Translated by E Newman. London: A. \& C. Black.

- [1913a] 1974. "Geschichte der Leben-Jesu-Forschung." In Gesammelte Werke in fünf Bänden, vol. 3. Zweite Ausgabe, Hrsg. R Grabs. München: C.H. Beck.

- [1913b] 1962. "Concluding statement from Die Geschichte der LebenJesu-Forschung." In The ethical mysticism of Albert Schweitzer, edited by H Clark, 195-205. Boston: Beacon.

- [1922] 1956. On the edge of the primeval forest. London: Fontana.

- [1923a] 1974. "Verfall und Wiederaufbau der Kultur. Kulturphilosophie erster Teil”: 17-93. In Gesammelte Werke in fünf Bänden, vol. 2, Hrsg. R Grabs, 17-93. München: CH Beck.

— [1923b] 1974. "Kultur und Ethik. Kulturphilosophie zweiter Teil”: 95420. In Gesammelte Werke in fünf Bänden, vol. 2, Hrsg. R Grabs, 95420. München: C.H. Beck.

- 1924. Memoirs of childhood and youth. Translated by CT Campion. London: Allen \& Unwin.

- [1931a] 1974. "Aus meinem Leben und Denken": 19-252. In Gesammelte Werke in fünf Bänden, vol. 1, Hrsg. R Grabs, 19-252. München: CH Beck.

- [1931b] 1974. "Die Mystik des Apostels Paulus": 15-509. In Gesammelte Werke in fünf Bänden, vol. 4, Hrsg. R Grabs, 15-509. München: C.H. Beck.

- [1933] 1998. Out of my life and thought: an autobiography. Translated by AB Lemke. Baltimore: Johns Hopkins University Press.

- [1934] 2009. "Religion in modern civilization." In Albert Schweitzer's ethical vision: a sourcebook, edited by P Cicovacki, 75-83. Oxford: Oxford University Press.

- [1935] 1974. "Die Weltanschauung der indischen Denker": 421-663. In Gesammelte Werke in fünf Bänden, vol. 2, Hrsg. R Grabs, 421-663. München: C.H. Beck.

- [1936a] 1962. "The ethics of reverence for life." In The ethical mysticism of Albert Schweitzer, edited by H Clark, 180-94. Boston: Beacon.

- 1936b. Indian thought and its development. Translated by CEB Russell. Boston: Beacon Press.

- [1936c] 2009. “The ethics of reverence for life." In Albert Schweitzer's ethical vision: a sourcebook, edited by P. Cicovacki, 153-64. Oxford: Oxford University Press. 
- 1939. Christianity and the religions of the world. Translated by J Powers. London: Allen \& Unwin.

- 1953. The mysticism of Paul the Apostle. Translated by W Montgomery. London: A \& C Black.

- [1959] 1987. The philosophy of civilization. Translated by CT Campion. New York: Macmillan, Prometheus Books.

- 1965. The teaching of reverence for life. Translated by R Winston and C Winston. New York: Holt, Rinehart \& Winston.

- 1966. Straßburger Predigten. Hrsg. U Neuenschwander. München: CH Beck.

- [1969] 1974. Reverence for life. Translated by RH Fuller. London: SPCK.

- 1986. A place for revelation: sermons on reverence for life. Translated by DL Holland. New York: Macmillan.

- 1992. Letters, 1905 - 1965. Edited by HW Bähr. Translated by J Neugroschel. New York: Macmillan.

- 1999. Kulturphilosophie III. Erster und zweiter Teil. In Die Weltanschauung der Ehrfurcht vor dem Leben. Hrsg. C Günzler and J Zürcher. Werke aus dem Nachlaß. München: $\mathrm{CH}$ Beck.

- 2000a. Kulturphilosophie III. Dritter und vierter Teil. In Die Weltanschauung der Ehrfurcht vor dem Leben. Hrsg. C Günzler and J Zürcher. Werke aus dem Nachlaß. München: $\mathrm{CH}$ Beck.

- 2000b. The quest of the historical Jesus: first complete edition. Edited by J Bowden. Translated by WBD Montgomery, JR Coates and S Cupit. London: SCM Press.

- 2003. The African sermons. Edited by SEG Melamed. Syracuse: Syracuse University Press.

- 2006. Theologischer und philosophischer Briefwechsel 1900 - 1965. Werke aus dem Nachlaß. München: Verlag CH Beck.

Spiegelberg, Herbert 1975. "Good fortune obligates: Albert Schweitzer's second ethical principle.” Ethics 85, no. 3:227-34.

Van Aarde, AG 2003. "Does historical Jesus research have a future?" Verbum et Ecclesia 24, no. 2: 533-56. 